\title{
, \\ IQM-PC332, a Novel DREAM Ligand with Antinociceptive Effect on Peripheral Nerve Injury-Induced Pain
}

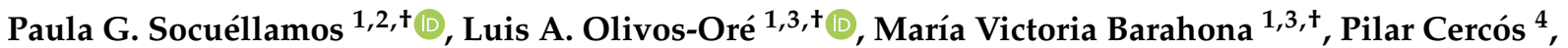 \\ Marta Pérez Pascual 1, Marina Arribas-Blázquez ${ }^{1,3}$, José Ramón Naranjo 5,6, Carmen Valenzuela 2,7 (D), \\ Marta Gutiérrez-Rodríguez ${ }^{4, *(\mathbb{D})}$ and Antonio R. Artalejo 1,3,*(D)
}

Citation: Socuéllamos, P.G.; Olivos-Oré, L.A.; Barahona, M.V.;

Cercós, P.; Pérez Pascual, M. Arribas-Blázquez, M.; Naranjo, J.R.; Valenzuela, C.; Gutiérrez-Rodríguez, M.; Artalejo, A.R. IQM-PC332, a Novel DREAM Ligand with Antinociceptive Effect on Peripheral Nerve Injury-Induced Pain. Int. J Mol. Sci. 2022, 23, 2142. https:// doi.org/10.3390/ijms23042142

Academic Editor: Irmgard Tegeder

Received: 22 December 2021

Accepted: 12 February 2022

Published: 15 February 2022

Publisher's Note: MDPI stays neutral with regard to jurisdictional claims in published maps and institutional affiliations.

Copyright: (c) 2022 by the authors Licensee MDPI, Basel, Switzerland. This article is an open access article distributed under the terms and conditions of the Creative Commons Attribution (CC BY) license (https:// creativecommons.org/licenses/by/ $4.0 /)$
1 Department of Pharmacology and Toxicology, Veterinary Faculty and Instituto Universitario de Investigación en Neuroquímica (IUIN), Universidad Complutense de Madrid, 28040 Madrid, Spain; paulagarcia@iib.uam.es (P.G.S.); olivos@ucm.es (L.A.O.-O.); vbg@ucm.es (M.V.B.); martpe13@ucm.es (M.P.P.); marina.arribas@vet.ucm.es (M.A.-B.)

2 Instituto de Investigaciones Biomédicas Alberto Sols (IIBM), CSIC-UAM, 28029 Madrid, Spain; cvalenzuela@iib.uam.es

3 Instituto de Investigación Sanitaria San Carlos, 28040 Madrid, Spain

4 Instituto de Química Médica (IQM-CSIC), 28006 Madrid, Spain; pcercos@nebrija.es

5 Centro Nacional de Biotecnología-Consejo Superior de Investigaciones Científicas (CSIC), 28049 Madrid, Spain; naranjo@cnb.csic.es

6 Centro de Investigación Biomédica en Red Enfermedades Neurodegenerativas (CIBERNED), 28031 Madrid, Spain

7 Centro de Investigación Biomédica en Red Enfermedades Cardiovasculares (CIBERCV), 28029 Madrid, Spain

* Correspondence: mgutierrez@iqm.csic.es (M.G.-R.); artalejo@ucm.es (A.R.A.); Tel.: +34-91-258-7493 (M.G.-R.); +34-913-943-851 (A.R.A.)

+ These authors contributed equally to this work.

\begin{abstract}
Neuropathic pain is a form of chronic pain arising from damage of the neural cells that sense, transmit or process sensory information. Given its growing prevalence and common refractoriness to conventional analgesics, the development of new drugs with pain relief effects constitutes a prominent clinical need. In this respect, drugs that reduce activity of sensory neurons by modulating ion channels hold the promise to become effective analgesics. Here, we evaluated the mechanical antinociceptive effect of IQM-PC332, a novel ligand of the multifunctional protein downstream regulatory element antagonist modulator (DREAM) in rats subjected to chronic constriction injury of the sciatic nerve as a model of neuropathic pain. IQM-PC332 administered by intraplantar $(0.01-10 \mu \mathrm{g})$ or intraperitoneal $(0.02-1 \mu \mathrm{g} / \mathrm{kg})$ injection reduced mechanical sensitivity by $\approx 100 \%$ of the maximum possible effect, with $\mathrm{ED}_{50}$ of $0.27 \pm 0.05 \mu \mathrm{g}$ and $0.09 \pm 0.01 \mu \mathrm{g} / \mathrm{kg}$, respectively. Perforated-patch whole-cell recordings in isolated dorsal root ganglion (DRG) neurons showed that IQM-PC332 (1 and $10 \mu \mathrm{M}$ ) reduced ionic currents through voltage-gated $\mathrm{K}^{+}$channels responsible for A-type potassium currents, low, T-type, and high voltage-activated $\mathrm{Ca}^{2+}$ channels, and transient receptor potential vanilloid-1 (TRPV1) channels. Furthermore, IQM-PC332 $(1 \mu \mathrm{M})$ reduced electrically evoked action potentials in DRG neurons from neuropathic animals. It is suggested that by modulating multiple DREAM-ion channel signaling complexes, IQM-PC332 may serve a lead compound of novel multimodal analgesics.
\end{abstract}

Keywords: DREAM/KChIP3/calsenilin; DREAM ligands; neuropathic pain; nociception; chronic constriction nerve-injury; dorsal root ganglion neuron

\section{Introduction}

Neuropathic pain is an unaddressed clinical problem due to its form of presentation (spontaneous pain, allodynia, and hyperalgesia), frequent chronicity, and the modest efficacy and dose-limiting effects of currently available drugs [1]. Neuropathic pain often involves a disfunction of primary nociceptive neurons having their soma in the dorsal 
root ganglions (DRG), which become hyperexcitable [2]. Abundant experimental evidence has linked changes in the expression and function of various ion channels (voltage-gated $\mathrm{Na}^{+}, \mathrm{Na}_{\mathrm{V}}, \mathrm{K}^{+}, \mathrm{K}_{\mathrm{V}}$, and $\mathrm{Ca}^{2+}, \mathrm{Ca}_{\mathrm{V}}$, channels, transient receptor potential vanilloid-1, TRPV1 channel, etc.) to hyperexcitability of DRG neurons in different models of neuropathic pain secondary to the injury of a peripheral nerve, thus making ion channels potential drug targets for the control of nociception [3]. In this context, an attractive strategy to achieve an effective and, above all, safe analgesic effect could be the development of drugs capable of interacting with the modulatory subunits of the channels rather than directly with their pore forming units.

The downstream regulatory element antagonist modulator (DREAM) is a multifunctional protein belonging to the family of neuronal $\mathrm{Ca}^{2+}$ sensors [4]. Initially identified as calsenilin, a presenilin binding protein [5], was rapidly recognized also as a transcriptional repressor through the association with DRE (Downstream Regulatory Element) sites [6], and a potassium channel interacting protein (KChIP3) that regulates the intracellular traffic and biophysical properties of $\mathrm{K}_{\mathrm{V}} 4$ channels [7]. Besides modifying the expression of several genes involved in pain perception, like c-fos [6], brain derived neurotrophic factor (BDNF) [8,9], prodynorphin [6,10], cathepsin L [11] or interleukins 2 and 4 [12], DREAM also interacts with a variety of ion channels and receptors involved in pain detection and transmission in DRG neurons. This is the case of NMDA glutamate receptors [13], TRPV1 channels [14], and a variety of voltage-activated channels, including $\mathrm{K}_{\mathrm{V}} 4.3$ channels responsible for the transient, A-type, potassium current $\left(\mathrm{I}_{\mathrm{A}}\right)$ [15], and the low, T-type [16], and high voltage-activated (HVA), L-type [17] $\mathrm{Ca}_{\mathrm{v}}$ channels. Of note, except for NMDA receptors, DREAM acts to enhance currents through these channel types. Importantly, DREAM is expressed in DRG neurons [14,18,19], which would make it a suitable target for drugs potentially producing an analgesic effect by acting as DREAM ligands.

Here we investigated the mechanical antinociceptive effect of the a novel DREAM ligand IQM-PC332 (2-[2-(3,4-Dichlorophenyl)acetylamino]-4-(4'-n-butylphenyl)benzoic acid) in rats subjected to chronic constriction injury of the sciatic nerve (CCI), a common model of post-traumatic neuropathic pain. IQM-PC332 is known to bind with high affinity to DREAM $\left(\mathrm{K}_{\mathrm{D}}=0.28 \mu \mathrm{M}\right.$ in the surface plasmon resonance assay) and to inhibit currents through $\mathrm{K}_{\mathrm{V}} 4.3$ /DREAM channels expressed in African green monkey kidney-derived CHO-K1 (CHO) cells with an $\mathrm{IC}_{50}=6.8 \mu \mathrm{M}[20,21]$. Here, we show that IQM-PC332 exerts an antinociceptive effect upon local and systemic administration. Importantly, IQMPC332 blocks $\mathrm{I}_{\mathrm{A}}$ in rat DRG neurons with a similar potency and efficacy as it inhibits $\mathrm{K}_{\mathrm{v}}$ 4.3/DREAM channels in CHO cells; likewise, IQM-PC332 reduces currents mediated by T-type and HVA Ca $\mathrm{V}_{\mathrm{v}}$ channels as well as TRPV1 channels in DRG neurons, all of which being actions that may underlie its analgesic effect. It is proposed that by modulating DREAM-ion channel interactions, small DREAM ligands may open new avenues for a "single-drug" multimodal analgesia.

\section{Results}

\subsection{Effect of IQM-PC332 on Mechanical Sensitivity in CCI Animals}

Mechanical sensitivity was evaluated before (baseline) and after CCI surgery, and was observed only in the CCI-injured hind paw. The paw withdrawal threshold (PWT) at baseline was $33.16 \pm 0.98 \mathrm{~g}$ and was reduced to $12.83 \pm 0.44(n=5)$ after CCI surgery, hence reflecting mechanical hypersensitivity (Figure 1). Importantly, the decrease in PWT to tactile stimulation remained stable from day 7 to day 21 post-CCI surgery so that the drug's effects in vivo and in vitro could be studied during this time window.

The effect of IQM-PCC32 on mechanical sensitivity was assessed following intraplantar (i.pl.) and intraperitoneal (i.p.) administration. Intraplantar administration of IQM-PC332 (0.01-10 $\mu \mathrm{g})$ in the affected hind paw increased PWT values while vehicle (dimethyl sulfoxide, DMSO, 3\%) had no effect. PWT values were normalized by calculating the percentage of the maximum possible effect (\%MPE), which peaked at $\approx 100 \%$ for the $10 \mu \mathrm{g}$ dose (PWT of $32.28 \pm 2.37 ; n=5$ ). Likewise, the ED 50 for the effect of IQM-PC332 after 
i.pl. administration was $0.27 \pm 0.05 \mu \mathrm{g}$ (Figure 1a). Intraperitoneal administration of IQM-PC332 $(0.02-1 \mu \mathrm{g} / \mathrm{kg})$ also reduced mechanical sensitivity in the affected hind paw. $\%$ MPE was $\approx 100 \%$ at the $1 \mu \mathrm{g} / \mathrm{kg}$ dose (PWT of $36.13 \pm 3.98 ; n=5$ ) and the $\mathrm{ED}_{50}$ was $0.09 \pm 0.01 \mu \mathrm{g} / \mathrm{Kg}$ (Figure 1b). Interestingly, no effect of the drug on mechanical sensitivity could be observed in the contralateral, uninjured, hind paw (data not shown). Although this observation suggests that IQM-PC332 does not affect motor coordination, this issue was directly investigated with the RotaRod test. In Control, non-operated animals, IQMPC332 $(1 \mu \mathrm{g} / \mathrm{kg}$, i.p. $)$ did not affect the time to fall of the animals as compared to vehicle (data not shown). Altogether, these results indicate that IQM-PC332 attenuates mechanical hypersensitivity dose-dependently in the CCI model of neuropathic pain.

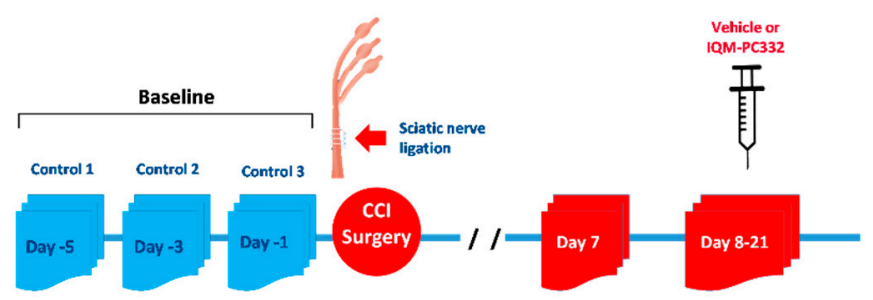

a
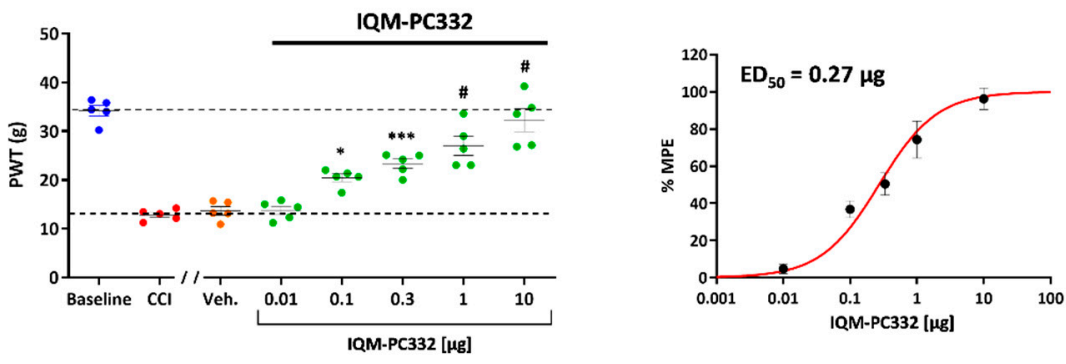

b
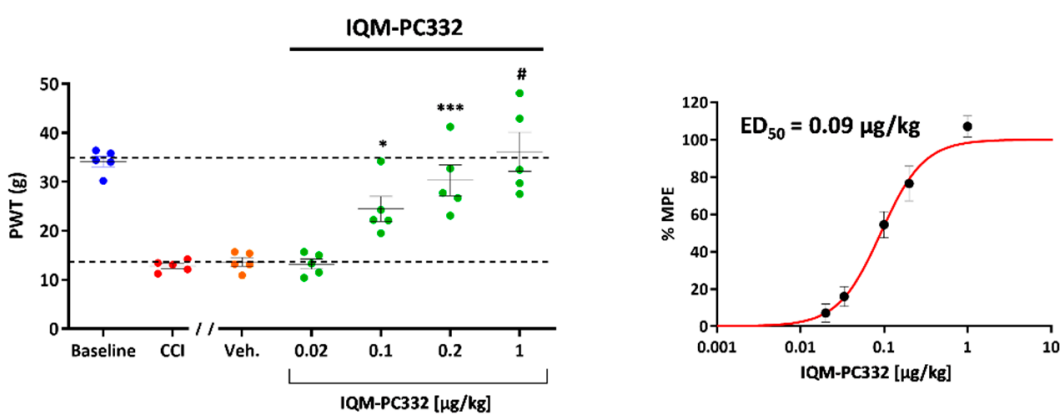

Figure 1. Effect of IQM-PC332 on mechanical sensitivity in CCI animals. A graphical scheme of the experimental design is depicted on top of the figure. IQM-PC332 or vehicle (DMSO, 3\%) were administered by intraplantar (i.pl.) or intraperitoneal (i.p.) injection at $48 \mathrm{~h}$ intervals starting on day 7 after CCI surgery. Pre-CCI values (designated as Baseline) were taken as the mean of three determinations performed on days $-5,-3$, and -1 with respect to CCI surgery. (a) Left panel. Effect of IQM-PC332 on the paw withdrawal threshold (PWT) following i.pl. administration. Right panel. Doseresponse curve of the effect of IQM-PC332 expressed as the percentage of the maximum possible effect (\%MPE). (b) Left panel. Effect of IQM-PC332 on the paw withdrawal threshold (PWT) following i.p. administration. Right panel. Dose-response curve of the effect of IQM-PC332 expressed as the percentage maximum possible effect (\%MPE). Dashed lines in left panels indicate PWT values at Baseline and 7 days after CCI. Data are given as the mean \pm SEM of 5 measurements $(n=5$ animals) for each administration route. Statistical significance was assessed by two-way ANOVA, followed by a Bonferroni's post hoc test for comparisons at different doses with respect to vehicle. *: $p<0.05$; $* * *: p<0.001 ; \#: p<0.0001$. 


\subsection{Effect of IQM-PC332 on $I_{A}$ in DRG Neurons}

IQM-PC332 has been characterized as an inhibitor of $\mathrm{K}_{\mathrm{v}} 4.3$ /DREAM channels expressed in a heterologous system $[20,21]$. Since DRG neurons express DREAM as well as $\mathrm{K}_{\mathrm{v}} 4.3$ channels, which contribute to $\mathrm{I}_{\mathrm{A}}[14,22,23]$, we first set out to record $\mathrm{I}_{\mathrm{A}}$ in $\mathrm{DRG}$ neurons from unoperated, Control, animals to evaluate the effect of IQM-PC332 on native potassium channels. Figure $2 \mathrm{a}$, c shows transient, fast activating and inactivating potassium currents in the voltage-range in which $\mathrm{I}_{\mathrm{A}}$ makes a substantial contribution to $\mathrm{K}_{\mathrm{v}}$ currents (from $-20 \mathrm{mV}$ to $+20 \mathrm{mV}$ ). These currents were sensitive to $5 \mathrm{mM} 4$-aminopyridine (data not shown) and displayed biexponential inactivation kinetics (Figure 2a). Time constants of the fast $\left(\tau_{\mathrm{f}}\right)$ and slow $\left(\tau_{\mathrm{s}}\right)$ components at $0 \mathrm{mV}$ were $5.26 \pm 0.56 \mathrm{~ms}$ and $136.86 \pm 22.48 \mathrm{~ms}$, respectively, the fast component accounting for $28.03 \pm 4.71 \%$ of the process $(n=14$ cells). As previously reported [22], time constants exhibited weak voltage-dependence (Figure 2d). IQM-PC332 at $1 \mu \mathrm{M}$ and $10 \mu \mathrm{M}$ reduced the peak amplitude of $\mathrm{I}_{\mathrm{A}}$ dose-dependently, the effect being particularly larger at $10 \mu \mathrm{M}$ in the range from 0 to $+20 \mathrm{mV}$ (Figure 2a). This partly reflects the voltage dependence of the block at $1 \mu \mathrm{M}$, which decreases with the depolarization (percent block of $24.12 \pm 8.97 \%$ and $6.82 \pm 5.63$ at $-20 \mathrm{mV}$ and $+20 \mathrm{mV}$, respectively; $n=7$ cells), and that would be consistent with a preferential binding of the drug to the close-activated state of the channel (Figure 2b). IQM-PC332 $1 \mu \mathrm{M}$ slightly accelerated current inactivation by reducing $\tau_{\mathrm{s}}$, whereas at $10 \mu \mathrm{M}$ it slowed the inactivation by increasing both $\tau_{\mathrm{f}}$ and $\tau_{\mathrm{s}}$ (Figure $2 \mathrm{c}, \mathrm{d}$ ). These results are in line with those reported for heterologously expressed $K_{\mathrm{v}} 4.3$ /DREAM channels and point to a similar effect of IQM-PC332 on native $\mathrm{K}_{\mathrm{v}} 4.3$ /DREAM channels.

Next, we measured $\mathrm{I}_{\mathrm{A}}$ in DRG neurons from CCI animals. In agreement with previous reports [24,25], there was a decrease of $\mathrm{I}_{\mathrm{A}}$ in these neurons (Figure S1). At $+20 \mathrm{mV}$, peak $\mathrm{I}_{\mathrm{A}}$ in DRG neurons from CCI animals was $49.91 \pm 2.14 \mathrm{pA} / \mathrm{pF}(n=10$ cells $)$, which was significantly smaller than that recorded from Control animals $(65.15 \pm 1.77 \mathrm{pA} / \mathrm{pF}$; $n=14$ cells; $p<0.0001)$. IQM-PC332 $(1 \mu \mathrm{M}$ and $10 \mu \mathrm{M})$ also inhibited peak amplitude of $\mathrm{I}_{\mathrm{A}}$ dose-dependently in DRG neurons from neuropathic animals. No significant difference in percent block was observed at $-20 \mathrm{mV}$ for $1 \mu \mathrm{M}(33.15 \pm 7.20 \% ; n=5$ cells $)$ and $10 \mu \mathrm{M}$ $(66.74 \pm 13.36 \% ; n=5$ cells) IQM-PC332 with regard to Control animals $(23.98 \pm 6.40 \%$ and $29.41 \pm 6.29 \%$ for 1 and $10 \mu \mathrm{M}$, respectively; $n=7$ cells for each drug concentration), thereby implying a similar action of the drug on $\mathrm{I}_{\mathrm{A}}$ in DRG neurons from Control and CCI animals (Figure S1).

\subsection{Effect of IQM-PC332 on T-Type and HVA $\mathrm{Ca}^{2+}$ Currents in DRG Neurons}

$\mathrm{Ca}_{\mathrm{V}}$ channels are known to play a key role in the control of excitability and neurotransmitter release in DRG neurons [26-28]. They act as "pronociceptive" channels [27,29,30] and, consequently, are potential drug targets for the treatment of acute and chronic pain [31,32].

We characterized the effect of IQM-PC332 on T-type and HVA Ca ${ }^{2+}$ currents in DRG neurons from both Control and CCI animals. T-type and HVA Ca ${ }^{2+}$ currents differ in voltage for activation as well as in inactivation and deactivation kinetics [33]. T-type $\mathrm{Ca}^{2+}$ currents activate at low voltages, $\approx-50 \mathrm{mV}$, reach maximal amplitude at $-40 \mathrm{mV}$, undergo fast and pronounced inactivation, and show slow deactivation upon repolarization; at variance, $\mathrm{HVA} \mathrm{Ca}^{2+}$ currents start to activate at $\approx-30 \mathrm{mV}$, peak at $-10 \mathrm{mV}$, and exhibit slow inactivation. We made use of a series of step-like depolarizations from a $\mathrm{V}_{\mathrm{h}}=-80 \mathrm{mV}$ up to $+20 \mathrm{mV}$ in $10 \mathrm{mV}$ increments to record both T-type and HVA Ca ${ }^{2+}$ currents in DRG neurons (Figure 3). In cells from Control animals, small size T-type $\mathrm{Ca}^{2+}$ currents were observed in the voltage range between -50 and $-30 \mathrm{mV}(3.53 \pm 0.99 \mathrm{pA} / \mathrm{pF}$ at $-40 \mathrm{mV}$; $n=5$ cells); in line with previous reports [34], DRG neurons from CCI animals exhibited larger T-type $\mathrm{Ca}^{2+}$ currents, with notorious transient kinetics on sustained depolarization $(11.56 \pm 2.60 \mathrm{pA} / \mathrm{pF}$ at $-40 \mathrm{mV} ; n=7$ cells; $p=0.03)$ (Figure 3a). Accordingly, I-V curves exhibited a single peak corresponding to $\mathrm{HVA} \mathrm{Ca}^{2+}$ currents in DRG neurons from Control animals $(111.40 \pm 7.84 \mathrm{pA} / \mathrm{pF}$ at $-10 \mathrm{mV})$, while a prominent peak of $\mathrm{HVA} \mathrm{Ca}^{2+}$ currents 
$(86.73 \pm 10.48 \mathrm{pA} / \mathrm{pF}$ at $-10 \mathrm{mV} ; p>0.05)$ preceded by a hump, the latter corresponding to T-type $\mathrm{Ca}^{2+}$ currents, was observed in DRG neurons from CCI animals (Figure $3 b$ ).

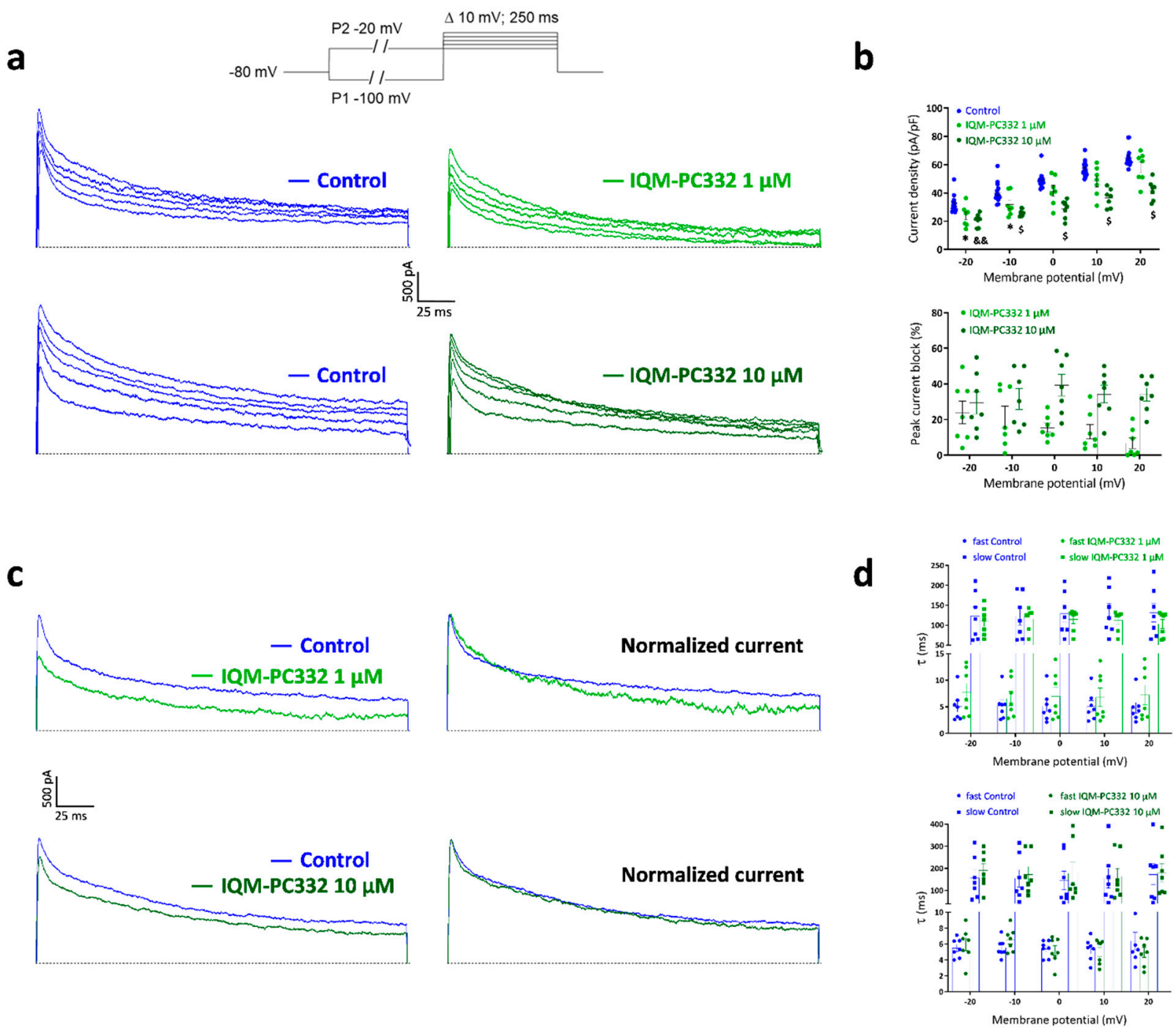

Figure 2. Effect of IQM-PC332 on peak amplitude and inactivation kinetics of $I_{A}$ in DRG neurons from Control animals. (a) Representative recordings of $\mathrm{I}_{\mathrm{A}}$ isolated by using the voltage protocol depicted on top of the panels. The effect of IQM-PC332 $1 \mu \mathrm{M}$ (upper panel) or $10 \mu \mathrm{M}$ (lower panel) is shown. (b) Upper panel. Peak current density to voltage (I-V) relation in the absence (Control) and presence of IQM-PC332 $1 \mu \mathrm{M}$ and $10 \mu \mathrm{M}$, obtained from experiments as depicted in a; lower panel. Percent block of peak $\mathrm{I}_{\mathrm{A}}$ by IQM-PC332 $(1 \mu \mathrm{M}$ and $10 \mu \mathrm{M})$ at different potentials. (c) Effect of IQM-PC332 $1 \mu \mathrm{M}$ (upper panel) and $10 \mu \mathrm{M}$ (lower panel) on inactivation kinetics of $\mathrm{I}_{\mathrm{A}}$. Currents evoked at $0 \mathrm{mV}$ (left panels) from a were normalized to peak $\mathrm{I}_{\mathrm{A}}$ in the absence of IQM-PC332 (right panels) to appreciate better the change in inactivation kinetics. (d) Effect of IQM-PC332 at $1 \mu \mathrm{M}$ (upper graph) or $10 \mu \mathrm{M}$ (lower graph) on time constants of inactivation at different potentials. The current records were fitted to a biexponential equation to obtain $\tau_{\mathrm{f}}$ and $\tau_{\mathrm{s}}$ values. Data are mean \pm SEM from 7 cells (membrane capacitance of $29.92 \pm 0.51 \mathrm{pF}$ ) for IQM-PC332 $1 \mu \mathrm{M}$, and 7 cells (membrane capacitance of $34.54 \pm 1.34 \mathrm{pF}$ ) for IQM-PC332 $10 \mu \mathrm{M}$. Statistical significance in (b) was assessed by two-way ANOVA, followed by a Bonferroni's post hoc test for multiple comparisons with respect to Control (membrane capacitance of $32.23 \pm 0.94 \mathrm{pF} ; n=14$ cells). *: $p<0.05$ for $1 \mu \mathrm{M} ; \& \&: p<0.01$, and $\$: p<0.0001$ for $10 \mu \mathrm{M})$. 
a
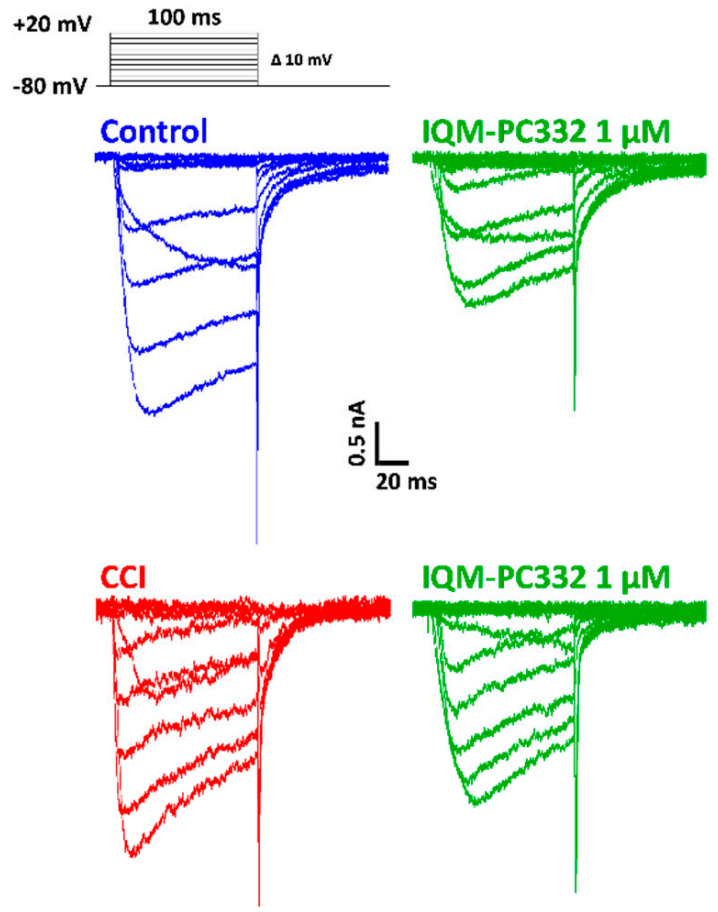

b
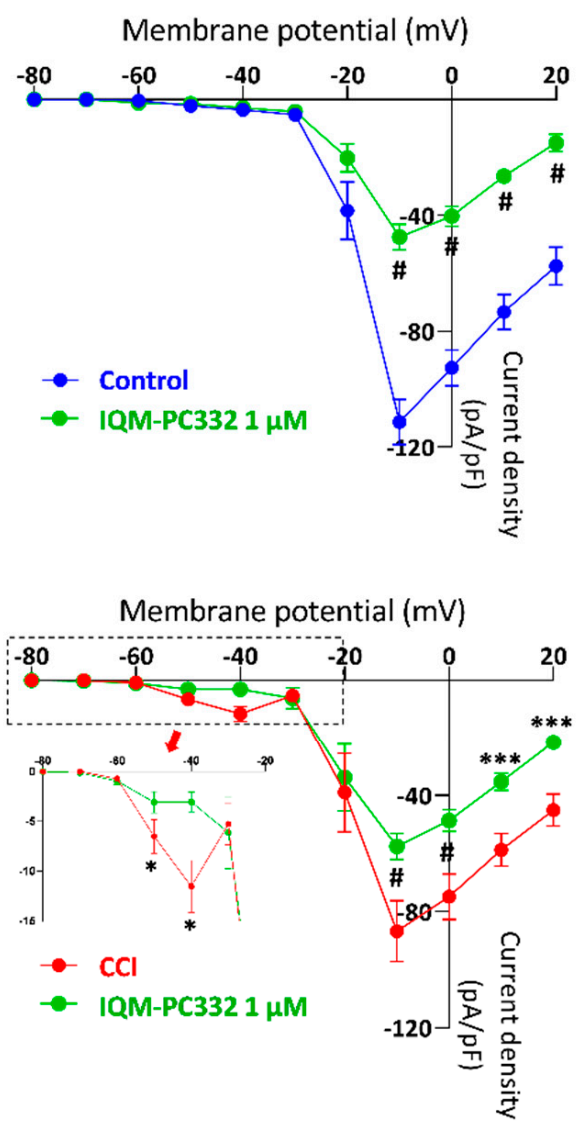

Figure 3. Effect of IQM-PC332 $(1 \mu \mathrm{M})$ on T-type and HVA Ca ${ }^{2+}$ currents in DRG neurons from Control and CCI animals. (a) Representative recordings of T-type and $\mathrm{HVA} \mathrm{Ca}^{2+}$ currents in DRG neurons from Control and CCI animals in the absence and presence of IQM-PC332 $1 \mu \mathrm{M}$. Currents were evoked by voltage pulses as depicted in the inset. (b) Peak I-V curves obtained from current traces in Control (upper panel) and CCI (lower panel) DRG neurons in experiments as depicted in (a). The inset in the lower panel shows an expanded view of the I-V curve at negative potentials (from $-80 \mathrm{mV}$ to $-20 \mathrm{mV}$ ). Data are mean \pm SEM of 5 (membrane capacitance of $29.02 \pm 0.92 \mathrm{pF}$ ) and 7 (membrane capacitance of $29.37 \pm 1.14 \mathrm{pF}$ ) cells per point from Control and CCI animals, respectively. Statistical significance was assessed by two-way ANOVA, followed by a Bonferroni's post hoc test for paired comparisons at different potentials with respect to Control or CCI. *: $p<0.05 ;{ }^{* * *}: p<0.001 ; \#: p<0.0001$.

IQM-PC332 $(1 \mu \mathrm{M})$ reduced $\mathrm{Ca}^{2+}$ currents at all voltages tested, thus suggesting an action on both T-type and HVA Ca $\mathrm{V}_{\mathrm{v}}$ channels (Figure 3a,b). It is of note that IQM-PC332 neither affected the kinetics of the current nor the position of the peak and the hump in I-V curves from Control and CCI animals (Figure $3 a, b)$.

To better determine the effect of IQM-PC332 $(1 \mu \mathrm{M})$ on T-type and HVA Ca ${ }^{2+}$ currents, we applied two different pulse protocols to record independently T-type and $\mathrm{HVA} \mathrm{Ca}^{2+}$ currents from the same cell [34] (Figure 4). T-type $\mathrm{Ca}^{2+}$ currents were elicited by a depolarization to $-40 \mathrm{mV}$ from a $\mathrm{V}_{\mathrm{h}}$ of $-80 \mathrm{mV}$, whereas $\mathrm{HVA} \mathrm{Ca}^{2+}$ currents were activated at $0 \mathrm{mV}$ from a $\mathrm{V}_{\mathrm{h}}$ of $-40 \mathrm{mV}$, which fully inactivates T-type $\mathrm{Ca}^{2+}$ currents. T-type and HVA Ca ${ }^{2+}$ currents hence recorded differed both in amplitude and kinetics in Control conditions, the former having a current density of $4.65 \pm 0.60 \mathrm{pA} / \mathrm{pF}$ ( $n=8$ cells) and a marked inactivation, while the latter inactivated barely but exhibited a much larger current density of $80.15 \pm 8.50 \mathrm{pA} / \mathrm{pF}$ (Figure $4 \mathrm{a}$ ). By using these protocols, we confirmed the enlargement of T-type $\mathrm{Ca}^{2+}$ currents in neurons from CCI animals $(9.64 \pm 1.50 \mathrm{pA} / \mathrm{pF}$; $n=8$ cells; $p=0.008)$ whereas HVA Ca ${ }^{2+}$ currents were mildly reduced as compared to Control conditions (72.62 $\pm 9.78 \mathrm{pA} / \mathrm{pF} ; p=0.57)$ (Figure $4 \mathrm{~b})$. IQM-PC332 (1 $\mu \mathrm{M})$ blocked both 
T-type and $\mathrm{HVACa}^{2+}$ currents in a statistically significant manner. Interestingly, percent block of $\mathrm{HVA} \mathrm{Ca}^{2+}$ currents was larger in cells from Control $(53.87 \pm 3.24 \%)$ than from CCI (36.54 $\pm 7.71 \% ; p=0.049)$ animals; inhibition of T-type $\mathrm{Ca}^{2+}$ currents by IQM-PC332 was similar in CCI cells $(30.71 \pm 9.95 \%)$ and Control ones $(28.19 \pm 6.12 \% ; p=0.83)$.

a
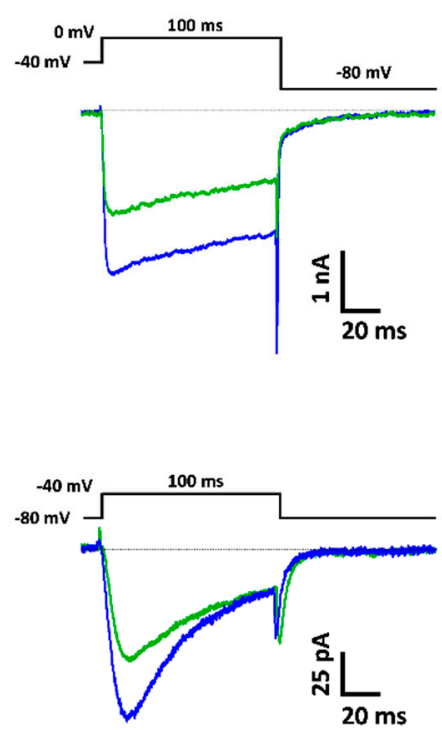
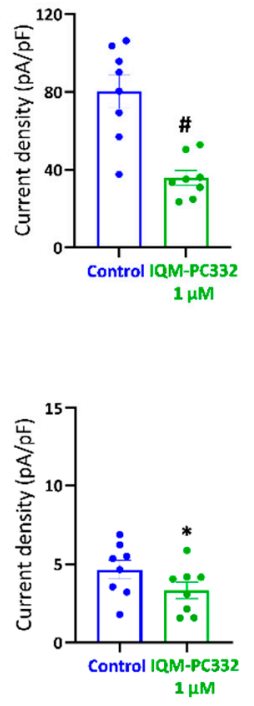

b
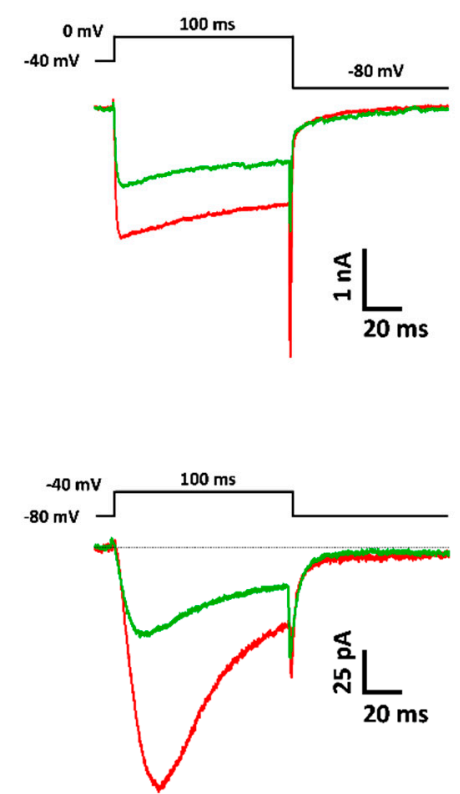

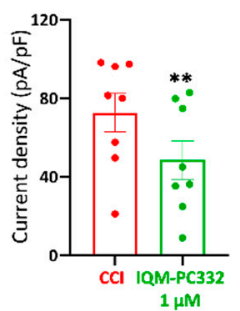

$\mathrm{CCl}$

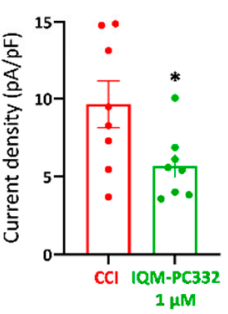

Figure 4. Effect of IQM-PC332 $(1 \mu \mathrm{M})$ on isolated T-type and HVA Ca ${ }^{2+}$ currents in DRG neurons from Control and CCI animals. Representative recordings of HVA (upper) and T-type (lower) $\mathrm{Ca}^{2+}$ currents in DRG neurons from Control (a) and CCI (b) animals in the absence (blue or red traces) and presence of IQM-PC332 $1 \mu \mathrm{M}$ (green traces). T-type $\mathrm{Ca}^{2+}$ currents were elicited by a depolarization to $-40 \mathrm{mV}$ from a $\mathrm{V}_{\mathrm{h}}$ of $-80 \mathrm{mV}$, whereas HVA Ca ${ }^{2+}$ currents were activated at $0 \mathrm{mV}$ from a $\mathrm{V}_{\mathrm{h}}$ of $-40 \mathrm{mV}$ (see voltage protocols at the top of the recordings). The scatter graphs show current density values for each condition. Data are mean \pm SEM from 8 cells for Control (25.96 $\pm 2.77 \mathrm{pF})$ and CCI $(28.29 \pm 3.03 \mathrm{pF})$ conditions. Statistical significances were assessed by using a Student's $t$-test for paired comparisons. ${ }^{*}: p<0.05 ;{ }^{* *}: p<0.01 ; \#: p<0.0001$.

\subsection{Effect of IQM-PC332 on TRPV1 Channels in DRG Neurons}

TRPV1 is a non-selective cation channel localized in peripheral sensory neurons where it activates in response to a variety of stimuli (heat, low $\mathrm{pH}$, endocannabinoids), but it can also be activated by natural compounds (i.e., capsaicin, resiniferatoxin, etc.) [35]. TRPV1 activation by capsaicin induces a nociceptive sensory neuron depolarization that translates into transient pain sensations. Interestingly, mechanical hypersensitivity in CCI animals is reversed by i.pl. administration of capsazepine $(30 \mu \mathrm{g})$, a TRPV1 channel blocker, thus suggesting the involvement of TRPV1 receptors in mechanical hypersensitivity (Figure S2).

We therefore investigated the ability of IQM-PC332 to modify the responses evoked by capsaicin in DRG neurons. Figure 5 shows that IQM-PC332 $(1 \mu \mathrm{M})$ markedly inhibited peak capsaicin $(0.1 \mu \mathrm{M})$ currents in cells from Control $(40.32 \pm 8.34 \mathrm{pA} / \mathrm{pF}$ in the absence, and $10.78 \pm 4.66 \mathrm{pA} / \mathrm{pF}$ in the presence of IQM-PC332; $n=11$ cells; $p<0.01)$ and CCI $(63.63 \pm 12.44 \mathrm{pA} / \mathrm{pF}$ in the absence, and $4.32 \pm 1.86 \mathrm{pA} / \mathrm{pF}$ in the presence of IQM-PC332; $n=9$ cells; $p<0.001)$ animals. Interestingly, TRPV1-mediated currents were upregulated in CCI animals ( $p=0.043)$ and percent block by IQM-PC332 was also larger in neurons from this type of animals (93.20\% in CCI animals versus $73.52 \%$ in Control ones). 

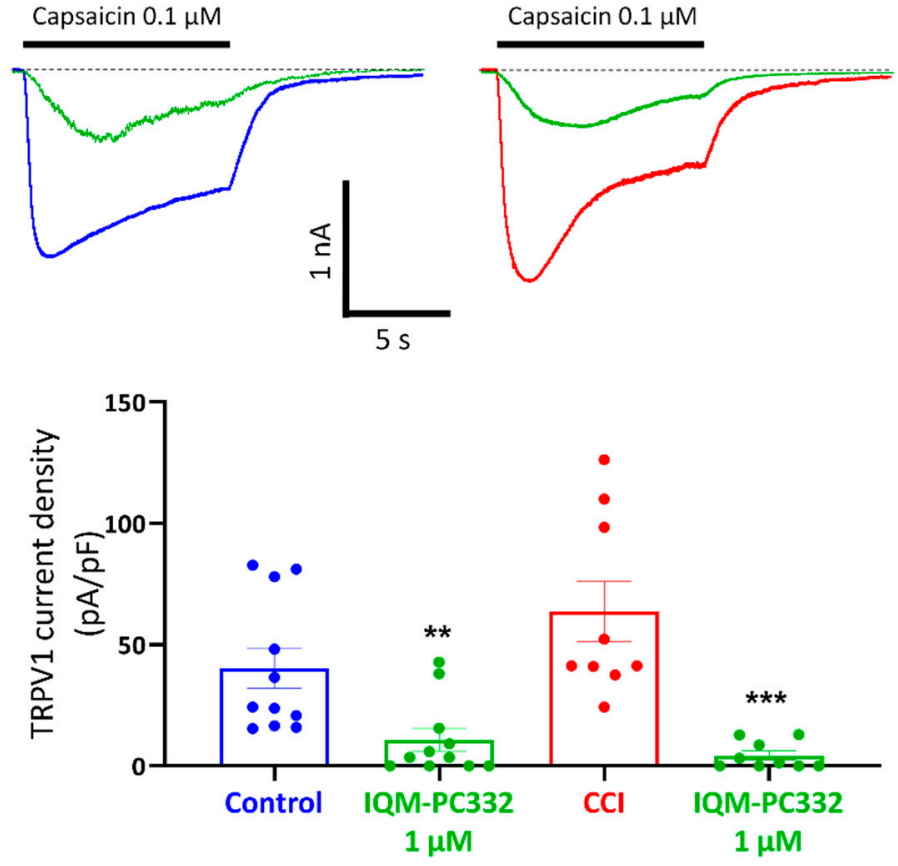

Figure 5. Effect of IQM-PC332 $(1 \mu \mathrm{M})$ on capsaicin-evoked currents in DRG neurons from Control and CCI animals. Upper panels. Representative recordings of $0.1 \mu \mathrm{M}$ capsaicin-evoked currents in the absence (blue or red) and the presence of IQM-PC332 (green) in DRG neurons from Control (upper left panel) and CCI (upper right panel) animals. Horizontal bars on top of the recordings indicate the time of capsaicin application. Lower panel. Scatter plot of peak current densities evoked by capsaicin in the absence and the presence of IQM-PC332 $(1 \mu \mathrm{M})$. Data are means \pm SEM from 11 (membrane capacitance of $28.46 \pm 2.44 \mathrm{pF}$ ) and 9 (membrane capacitance of $31.93 \pm 3.65 \mathrm{pF}$ ) cells of Control and CCI animals, respectively. Statistical significance was assessed by the Student's $t$-test for unpaired comparisons. ${ }^{* *}, p<0.01 ;{ }^{* * *}, p<0.001$ with respect to capsaicin alone.

\subsection{Effect of IQM-PC332 on Electrical Activity of DRG Neurons}

Last, we investigated the effect of IQM-PC332 $(1 \mu \mathrm{M})$ on electrical activity evoked by current injection in DRG neurons from both Control and CCI animals (Figure 6). Current injection evoked the firing of action potentials at higher frequency in neurons from CCI animals $(9.90 \pm 1.74 \mathrm{~Hz} ; n=5$ cells) than from Control ones $(3.90 \pm 0.91 \mathrm{~Hz} ; n=5$ cells; $p=0.0094)$, which suggests increased cellular excitability in nociceptive neurons from neuropathic animals as previously reported [25,36]. Interestingly, IQM-PC332 (1 $\mu \mathrm{M}) \mathrm{did}$ not affect the frequency of firing of action potentials in 3 out of 5 cells tested from Control animals, despite the fact that it consistently diminished the amplitude of action potential afterhyperpolarizations (AHP), in agreement with the marked inhibition of $\mathrm{HVA} \mathrm{Ca}^{2+}$ currents observed in these animals (Figure 6a). In contrast, IQM-PC332 $(1 \mu \mathrm{M})$ reduced the rate of action potential firing in 5 out of 5 cells from CCI animals. Of note, only a small reduction in AHP amplitude was observed in 2 cells, which is in accord with the lower effect of IQM-PC332 on HVA Ca ${ }^{2+}$ channels in neurons from CCI animals. This result points to the involvement of other channels in the effect of IQM-PC332 in electrical activity in DRG neurons from neuropathic animals (Figure 6b). 
a
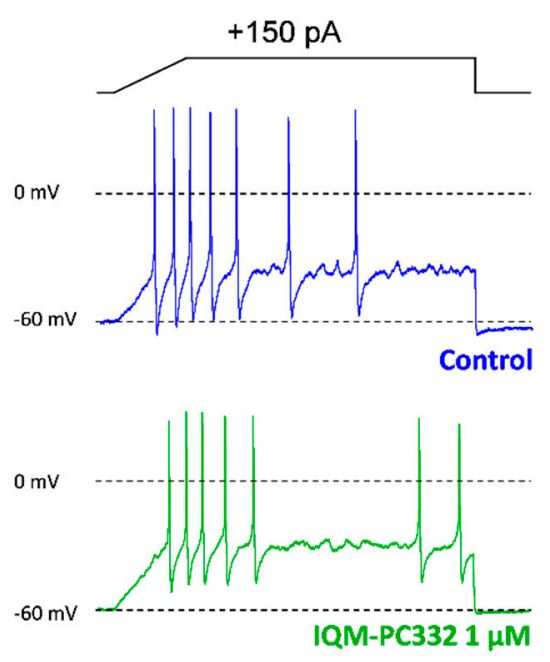

b
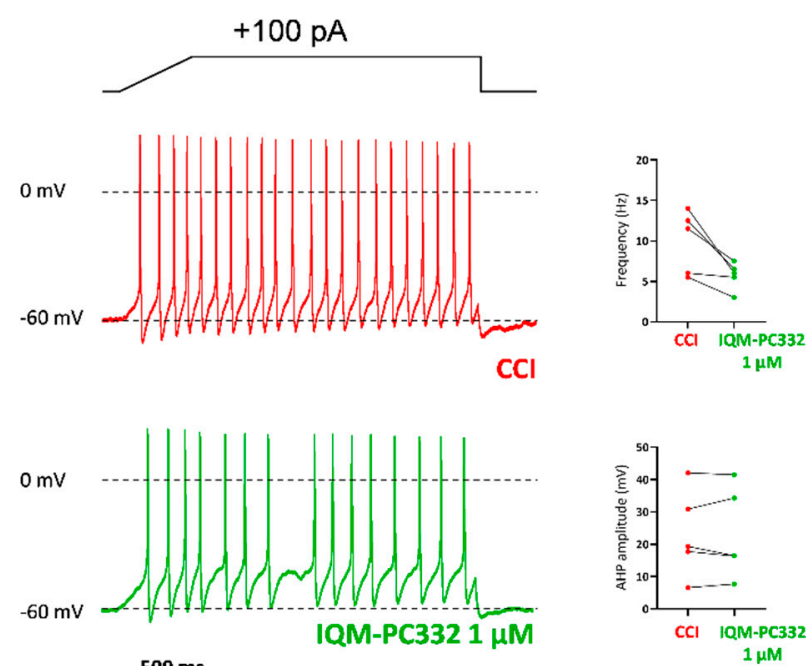

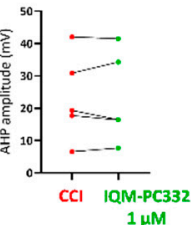

Figure 6. Effect of IQM-PC332 on electrical excitability in DRG neurons from Control and CCI animals. (a) Current-clamp recordings of action potentials evoked by current injection in DRG neurons from Control animals in the absence (blue) and the presence (green) of IQM-PC332 $(1 \mu \mathrm{M})$. (b) Current-clamp recordings of action potentials evoked by current injection in DRG neurons from CCI animals in the absence (blue) and the presence (green) of IQM-PC332 $(1 \mu \mathrm{M})$. Current protocols are shown at the top of the panels. Insets show before-after plots of action potential frequency and the amplitude of the action potential afterhyperpolarization (AHP). $\mathrm{V}_{\text {comm }}=-60 \mathrm{mV}$. Recordings are representative of those obtained in 5 cells from Control and CCI animals.

\section{Discussion}

We evaluated the effect of IQM-PC332, a novel DREAM ligand, on nociceptive hypersensitivity secondary to the injury of the rat's sciatic nerve, and on different ionic conductances and electrical excitability in primary nociceptive DRG neurons from Control and CCI animals. The main results show that IQM-PC332 reduced mechanical hypersensitivity in vivo and inhibited $\mathrm{I}_{\mathrm{A}}, \mathrm{Ca}_{\mathrm{v}}$ and TRPV1 currents as well as action potential firing in isolated neurons from CCI animals. It is therefore proposed that IQM-PC332 acts as a multimodal ion channel modulator to produce analgesia in animals with chronic nociceptive hypersensitivity.

IQM-PC332 alleviated mechanical hypersensitivity following acute i.pl. and i.p. administration. We tested mechanical sensitivity at the central part of the plantar surface of the hind paw, which in animals subjected to sciatic nerve injury reflects both the response of fibers of the tibial branch of the sciatic nerve and also of fibers of the saphenous nerve, that reinnervate the skin of the lesioned hind paw [37-39] The effect of the drug was clearly separated from that of the vehicle, was not confounded by a modification of motor coordination, and was not observed in Control, unoperated animals, hence excluding an action on normal nociception. Moreover, the antinociceptive effect was dose-dependent, reaching a maximum effect of $\approx 100 \%$. The fact that the effect is achieved by both local and systemic administration suggests a peripheral site of action, likely on DRG neurons, the primary nociceptive neurons in the pain pathway.

Nociceptive DRG neurons transduce noxious stimuli causing pain, thereby functioning as nociceptors, and generate action potentials that propagate to the spinal cord where nociceptive information is transmitted to the second-order sensory neurons, which will process and convey it to upper levels of the nervous system. Multiple ion channels are involved in sensing and transmitting nociceptive information in DRG neurons, including polymodal TRPV1 channels activated by a diversity of stimuli (thermal, mechanical and chemical) [35,40], $\mathrm{Na}_{\mathrm{v}}$ and $\mathrm{K}_{\mathrm{v}}$ channels, responsible for action potential generation [23,41], and $\mathrm{Ca}_{\mathrm{v}}$ channels, participating in both neurotransmitter release at central terminals and 
the regulation of action potential firing at the cell soma [31,32,42-44]. IQM-PC332 has been previously characterized as a potent ligand of DREAM that inhibits currents mediated by DREAM/ $\mathrm{K}_{\mathrm{v}} 4.3$ complexes in CHO cells with an $\mathrm{IC}_{50}$ of $6.8 \mu \mathrm{M}$ [20]. DRG neurons are known to express both DREAM (KChIP3) and $\mathrm{K}_{\mathrm{v}} 4.3$ channels, which contribute to $\mathrm{I}_{\mathrm{A}}[14,18,22,25]$. Our results indicate that IQM-PC332 modulates $\mathrm{I}_{\mathrm{A}}$ in DRG neurons, hence suggesting that it acts on native DREAM $/ \mathrm{K}_{\mathrm{v}} 4.3$ complexes at the plasma membrane. Importantly, IQM-PC332 dose-dependently $(1$ and $10 \mu \mathrm{M})$ inhibited peak $\mathrm{I}_{\mathrm{A}}$, and produced a small delay in current inactivation at $10 \mu \mathrm{M}$, both effects being consistent with those reported in $\mathrm{CHO}$ cells expressing DREAM/ $\mathrm{K}_{\mathrm{v}} 4.3$ complexes. Likewise, $\mathrm{I}_{\mathrm{A}}$ inhibition at $1 \mu \mathrm{M}$ IQM-PC332 appears to be voltage-dependent, diminishing with the depolarization, which in accordance with previous data suggests that the drug interacts with the close-activated state of the channel [45]. This implies that the effect of IQM-PC332 could wane during the peak of action potential, and thus have little impact on action potential repolarization.

We also investigated the effect of IQM-PC332 on other ionic conductances known to be modulated by DREAM, and which are also potential targets for analgesic drugs. IQM-PC332, also at concentrations at which it interacts with DREAM, reduced currents through T-type and HVA $\mathrm{Ca}_{\mathrm{v}}$ channels. The effect spans the voltage-range of activation of the two channel classes, so that a broad effect on DRG neuron function can be achieved. This effect would result mainly in the inhibition of neurotransmitter release at the central terminals of DRG neurons, which is controlled by presynaptic N- and P/Q-type, $\mathrm{HVAC \textrm {Ca } _ { \mathrm { v } }}$ channels [46,47], and in a reduction in action potential firing brought about by inhibition of T-type $\mathrm{Ca}_{\mathrm{v}}$ channels. Importantly, T-type $\mathrm{Ca}_{\mathrm{v}}$ channels are upregulated following $\mathrm{CCI}$ and contribute to the increased electrical excitability and glutamate release in DRG neurons of neuropathic animals (present results; [34,48]). By acting predominantly on hyperexcitable neurons, IQM-PC332 may exert a selective antinociceptive effect, and thus preserve normal nociception. This notion was substantiated by recording action potentials evoked by current injection in DRG neurons from Control and CCI animals. In Control cells, IQM-PC332 barely affected or even increase the rate of action potential firing. This effect could possibly be attributed to blockade of $\mathrm{HVA} \mathrm{Ca}_{\mathrm{v}}$ channels with the ensued reduction in the amplitude and duration of the AHP [49], as well as to the inhibition of $I_{A}$, which would shorten the interval between consecutive action potentials [50]. In contrast, in neurons from CCI animals, IQM-PC332 reduced the rate of firing as expected from a dominant effect on T-type $\mathrm{Ca}_{\mathrm{V}}$ channels that would counteract the possible effect on $\mathrm{I}_{\mathrm{A}}$ and $\mathrm{HVA} \mathrm{Ca}^{2+}$ currents, which are reduced in cells from neuropathic animals (present results; [25,49]).

Interestingly, CCI animals develop a TRPV1-related algesic tone as deduced from the ability of local capsazepine to alleviate mechanical hypersensitivity in the injured hind paw. This result points to TRPV1 channels as a therapeutic target in the CCI model of neuropathic pain. Importantly, IQM-PC332 $(1 \mu \mathrm{M})$ reduced TRPV1 channel currents, hence providing another possible mechanism of action for its analgesic effect.

In sum, the effects of IQM-PC332 on ion conductances in DRG neurons here reported would affect: (i) sensory transduction through inhibition of TRPV1 channels; (ii) frequency coding of information by decreasing $\mathrm{I}_{\mathrm{A}}$ and T-type $\mathrm{Ca}_{\mathrm{V}}$ channels, and (iii) synaptic transmission at the spinal cord by inhibiting $\mathrm{HVA} \mathrm{Ca}_{\mathrm{V}}$ channels. The effects on TRPV1 channels and on $\mathrm{Ca}_{\mathrm{v}}$ channels will depress DRG neuron function and are likely related to the behavioral effect of IQM-PC332. Importantly, upregulation of TRPV1 and T-type $\mathrm{Ca}_{\mathrm{V}}$ channels in DRG neurons, and the appearance of a capsazepine-sensitive tone in neuropathic animals [34,51], possibly explain why IQM-PC332 alleviates mechanical hypersensitivity without altering normal mechanical nociception.

IQM-PC332 thus acts as a multimodal ion channel modulator in DRG neurons. This would relate to its ability to perturb DREAM-ion channel interactions at the plasma membrane. IQM-PC332 modulation of $\mathrm{I}_{\mathrm{A}}$ in DRG neurons is consistent with previous data indicating that IQM-PC332 binds to DREAM and silences DREAM's effect on Kv4.3 channels expressed in CHO cells [20,21]. Likewise, the effect of IQM-PC332 on HVA Ca $\mathrm{a}_{\mathrm{V}}$ channels could be related to the fact that DREAM (KChIP3) coimmunoprecipitates with $\mathrm{HVA} \mathrm{Ca}_{\mathrm{v}} 1.2$ 
(L-type) channels and that IQM-PC332 blocks $\left(\mathrm{IC}_{50}\right.$ of $\left.32.64 \mathrm{nM}\right)$ such a DREAM-Ca channel interaction (J.R.N, personal communication). Interestingly, KChIP2, another member of the KChIP family, increases ion flux through cardiac L-type channels [17], which would give rationale to the inhibition of HVA Ca $\mathrm{a}_{\mathrm{v}}$ currents by IQM-PC332 in sensory neurons. Furthermore, DREAM interacts with TRPV1 channels to increase TRPV1 currents in DRG neurons [14], making sense of the inhibition of capsaicin-activated currents by IQM-PC332. Lastly, DREAM mediates the interaction between T-type $\mathrm{Ca}_{\mathrm{v}}$ channels and $\mathrm{K}_{\mathrm{v}} 4.3$ channels, so that the latter increases their availability to open in a $\mathrm{Ca}^{2+}$-dependent manner. It seems therefore plausible that by binding to DREAM, IQM-PC332 could inhibit T-type $\mathrm{Ca}_{\mathrm{v}}$ channels directly or indirectly through $\mathrm{K}_{\mathrm{v}} 4.3$ channels [16,52]. IQM-PC332 has been proposed to interact with multiple residues of DREAM (Leu96, Phe100, Ile117, Tyr118, Phe121, Tyr130, Phe151, Leu155, Leu158, Leu159, Ile194 and Ile256), which are mostly located in a large hydrophobic cavity surrounded by the $\mathrm{N}$ - and C-terminus of the protein $[20,21]$. Interestingly, both the $\mathrm{N}-[13,14]$ and C-terminus [52] of DREAM interact with ion channels, hence making it possible for IQM-PC332 to affect those interactions.

Although modulation of ion channels at the plasma membrane is the most likely mechanism underlying the analgesic effect of IQM-PC332, we cannot rule out an effect on gene expression. This is because behavioral evaluation was performed $20 \mathrm{~min}$ after drug administration, and IQM-PC332 has been shown to interfere with DREAM-mediated transcriptional repression of c-fos expression in STHdh $Q^{7 / 7}$ neuroblastoma cells in just 15 min after drug exposure [20]. Since DREAM controls prodynorphin and BDNF gene expression and both DREAM knock-out and its constitutive activation have been reported to affect nociceptive processing $[9,10,53]$, it is also possible that changes in gene expression could be involved in the antinociceptive effect of IQM-PC332.

In conclusion, IQM-PC332 could serve as lead compound for the development of novel DREAM ligands useful for a multimodal treatment of neuropathic pain by virtue of a concerted action on a variety of DREAM-interacting signaling complexes. Further studies for a clear separation of genomic and non-genomic effects of DREAM ligands will certainly lead to a better elucidation of the role of DREAM in nociception and of the therapeutic utility of small-drug DREAM ligands.

\section{Materials and Methods}

Adult male Sprague Dawley rats (weighing 200-220 g/6-8 weeks old) were used in the experiments. Animals were housed in transparent cages with temperature controlled at $23^{\circ} \mathrm{C}$ in a $12 \mathrm{~h}$ light/dark cycle room; water and food were provided ad libitum. All experimental procedures were conducted according to the animal welfare guidelines of the European Community (European Directive 2010/63/UE) to minimize animal suffering and were approved by Universidad Complutense de Madrid and Comunidad de Madrid Committee on Animal Experimentation (PROEX 207.8/21).

\subsection{Chronic Constriction Injury of The Sciatic Nerve}

CCI was performed according to Bennett and Xie (1988) [54]. Briefly, rats were anesthetized with i.p. ketamine (100 mg/kg; Merial Labs, Barcelona, Spain) and medetomidine $(100 \mu \mathrm{g} / \mathrm{kg}$; Esteve Labs, Barcelona, Spain). Under sterile conditions, approximately $7 \mathrm{~mm}$ of the right nerve was freed proximal to the sciatic trifurcation, and four barely constricting ligatures ( $1 \mathrm{~mm}$ apart) using $4 / 0$ chromic catgut were applied. The incision was closed in layers with silk thread 6/0. Animals were then allowed to recover from surgery for 7 days before being used in additional procedures.

\subsection{Behavioural Testing}

\subsubsection{Mechanical Sensitivity}

Rats were habituated to the experimental setting for at least $30 \mathrm{~min}$ before testing. All tests were conducted between 09:00 and 12:00. Mechanical sensitivity was evaluated with a dynamic plantar aesthesiometer (Ugo Basile, Gemonio, Italy) by means of a $0.5 \mathrm{~mm}$ filament 
exerting increasing force (up to $50 \mathrm{~g}$ over $20 \mathrm{~s}$ ) onto the central area of the plantar surface of the hind paw until the animal lifted its paw, the actual force at that time was automatically registered (paw withdrawal threshold; PWT). Hypersensitivity was defined as at least a $25 \%$ decrease in PWT compared with values before CCI surgery. PWT measurements were repeated 3 times at 5 min intervals, and the mean value was reported.

PWT determination was carried out before surgery (mean of 3 measurements on alternate days the week preceding surgery, collectively designated as Baseline) and on post-surgery days 7-21, when abnormal nociceptive behaviour was at a stable maximum. Neuropathic rats were allocated into 2 groups to receive IQM-PC322 and vehicle (DMSO $3 \%$ ) by either the i.pl. ( $20 \mu \mathrm{L} ; n=5$ animals) or i.p. ( $250 \mu \mathrm{L} ; n=5$ animals) route. Responses to mechanical stimulation were assessed $20 \mathrm{~min}$ before and $20 \mathrm{~min}$ after IQM-PC332 or vehicle injection. Each animal received six injections with a separation of $48 \mathrm{~h}$.

PWT values were transformed into percentage of the maximum possible effect (\%MPE), and \%MPE was calculated as follows: (Drug PWT-Vehicle PWT)/Baseline PWT)-Vehicle $\mathrm{PWT}) \times 100$. Dose-response curves and $\mathrm{ED}_{50}$ values were obtained by nonlinear regression with variable slope using version 8 (GraphPad Software, Inc., San Diego, CA, USA).

\subsubsection{Motor Coordination}

Motor coordination was assessed with a RotaRod apparatus (Ugo Basile, Gemonio, Italy). Non-operated rats were trained in the experimental procedure for at least two days. Motor coordination was evaluated through the time the animal spent on a roller rotating at a continuous speed (16 rpm). The cut-off time of $90 \mathrm{~s}$ was divided into two periods of $45 \mathrm{~s}$, and the times spent in each period were summed [55]. After obtaining control values, the animals were evaluated 30 min after i.p. administration of IQM-PC332 $(1 \mu \mathrm{g} / \mathrm{kg})$ or vehicle treatment (DMSO 3\%).

\subsection{Isolation of DRG Neurons}

Rats were sacrificed by cervical dislocation followed by decapitation and lumbar segments of the spinal column were removed and placed in a cold $\mathrm{Ca}^{2+}, \mathrm{Mg}^{2+}$-free Hank's solution (Sigma-Aldrich, Madrid, Spain). The bone surrounding the spinal cord was removed and the right L4, L5 and L6 DRG were exposed and pulled out. After removing the roots, DRG were chopped in half and incubated for $60 \mathrm{~min}$ at $37^{\circ} \mathrm{C}$ in Dulbecco's modified Eagle's Medium-low glucose (DMEM; Sigma-Aldrich) containing $5 \mathrm{mg} / \mathrm{mL}$ collagenase XI (Sigma-Aldrich, Madrid, Spain), $100 \mathrm{U} / \mathrm{mL}$ penicillin (Sigma-Aldrich), and $0.1 \mathrm{mg} / \mathrm{mL}$ streptomycin (Sigma-Aldrich). Then, the cell suspension was washed with DMEM by centrifugation ( $300 \mathrm{G}, 5 \mathrm{~min}$ at $\left.4{ }^{\circ} \mathrm{C}\right)$, filtered through a $100 \mu \mathrm{m}$ mesh to eliminate cell clumps and washed again by centrifugation. The cell pellet was resuspended in DMEM and $40 \mu \mathrm{L}$ was dropped onto $10 \mathrm{~mm}$ diameter glass coverslips treated with poly-d-lysine ( $1 \mathrm{mg} / \mathrm{mL}$, $30 \mathrm{~min}$; Sigma-Aldrich) placed in $35 \mathrm{~mm}$ diameter Petri dishes. Finally, plated cells were flooded with $2.5 \mathrm{~mL}$ of DMEM supplemented with $10 \%$ fetal calf serum (Sigma-Aldrich, Madrid, Spain), $100 \mathrm{U} / \mathrm{mL}$ penicillin and $0.1 \mathrm{mg} / \mathrm{mL}$ streptomycin, and stored in an incubator (Hera Cell, Heraeus, Hanau, Germany) in a $5 \% \mathrm{CO}_{2}$ atmosphere at $37^{\circ} \mathrm{C}$. This protocol yields spherical cell bodies without neurites, from which only small to medium DRG neurons (diameter $<30 \mu \mathrm{m}$ ) $[23,36]$ were chosen for recording within $12-24 \mathrm{~h}$ of plating.

\subsection{Electrophysiological Recordings}

All electrophysiological recordings were performed in the perforated-patch variant of the whole-cell configuration of the patch-clamp technique with an EPC10/2 amplifier using PatchMaster software (HEKA Electronic, Lambrecht, Germany) [56]. Patch pipettes were made from borosilicate glass and fire-polished to a resistance of 4.5-5.5 $\mathrm{M} \Omega$ when filled with an internal solution. Membrane currents were filtered at $3 \mathrm{kHz}$, and sampled at $10 \mathrm{kHz}$ from cells held at a voltage $\left(\mathrm{V}_{\mathrm{h}}\right)$ of $-80 \mathrm{mV}$. Series resistance $(<20 \mathrm{M} \Omega)$ was compensated by $80 \%$ and monitored throughout the experiment together with the cell 
membrane capacitance. Cells in which series resistance changed by more than $20 \%$ or holding current exceeded $20 \mathrm{pA}$ were discarded. Membrane potentials were recorded under current-clamp conditions and filtered at $3 \mathrm{kHz}$. Action potentials were evoked by current injection in DRG neurons from a $\mathrm{V}_{\text {comm }}$ of $-60 \mathrm{mV}$. Experiments were performed at room temperature $\left(22-25^{\circ} \mathrm{C}\right)$.

\subsubsection{Solutions and Drug Application}

The standard extracellular solution contained (mM) $145 \mathrm{NaCl}, 2.8 \mathrm{KCl}, 3 \mathrm{CaCl}_{2}, 1 \mathrm{MgCl}_{2}$, 10 4-(2-Hydroxyethyl)piperazine-1-ethanesulfonic acid, N-(2-Hydroxyethyl) piperazine-N'(2-ethanesulfonic acid) (HEPES), and 12 glucose (pH 7.35 adjusted with $\mathrm{NaOH}$; $320 \mathrm{mOsm}$ ) that was constantly superfused at a rate of approximately $1 \mathrm{~mL} \times \mathrm{min}^{-1}$. To eliminate currents through $\mathrm{Na}_{\mathrm{v}}$ channels during recordings of voltage-gated $\mathrm{Ca}^{2+}$ currents, the standard solution was modified by replacing $\mathrm{NaCl}$ with $\mathrm{N}$-Methyl-d-glucamine, the $\mathrm{pH}$ being adjusted with $\mathrm{HCl}$.

The internal solution used to record $\mathrm{K}_{\mathrm{v}}$ currents contained (mM) $145 \mathrm{KCl}, 2 \mathrm{MgCl}$, 0.3 EGTA, 0.3 GTP.Li , $_{3} 2$ ATP.Na 2,10 HEPES (pH 7.2 adjusted with $\mathrm{KOH} ; \approx 310 \mathrm{mOsm}$ ). In experiments aiming to isolate $\mathrm{Ca}_{\mathrm{v}}$ currents, the internal solution contained $(\mathrm{mM}): 140 \mathrm{CsCl}$, $2 \mathrm{MgCl}_{2}, 10$ EGTA, 0.3 GTP.Li $_{3}, 2$ ATP.Na 2,10 HEPES (pH 7.2 with CsOH; $\approx 307$ mOsm). The perforated-patch configuration was obtained using amphotericin B (Sigma-Aldrich). Amphotericin B was dissolved in dimethyl sulfoxide (DMSO) and stored at $-20{ }^{\circ} \mathrm{C}$ in aliquots of $50 \mathrm{mg} / \mathrm{mL}$. To seal the cells more easily, the patch pipette was immersed for a few seconds into an internal solution without amphotericin B and then back-filled with the internal solution containing amphotericin B (50-100 $\mu \mathrm{g} / \mathrm{mL})$. After sealing, series resistance decreased gradually to reach values below $20 \mathrm{M} \Omega$ within $10 \mathrm{~min}$. Fresh pipette solution containing amphotericin was prepared every $2 \mathrm{~h}$.

IQM-PC332, synthesized following protocols previoulsy described [20], was dissolved in DMSO at a stock concentration of $1 \mathrm{mM}$, and added to the external solution at the desired concentration in each experiment. The drug was directly applied for 2-4 min onto the cell under investigation by means of a multibarrel concentration-clamp device coupled to electronically driven miniature solenoid valves under the control of PatchMaster software. Capsaicin (Sigma-Aldrich) was dissolved in the extracellular solution to a concentration of $0.1 \mu \mathrm{M}$, and was applied with a glass-pipette (3-5 $\mu \mathrm{m}$ tip diameter) placed near $(5-10 \mu \mathrm{m})$ the cell of interest with a pneumatic drug ejection system (PDES-02DX, NPI Electronic $\mathrm{GmbH}$, Germany). Capasicin experiments in the absence and the presence of IQM-PC332 were conducted in separated cells to avoid TRPV1 channel desensitization upon repeated stimulation.

\subsubsection{Voltage/Current Protocols and Data Analysis}

Peak current-voltage (I-V) curves were built from current traces obtained with a series of step depolarizations associated with a $\mathrm{P} / 4$ protocol for on-line leak and capacitive current subtraction. Peak currents were transformed into peak current densities by dividing them by the membrane capacitance of each cell. Transient potassium current $\left(\mathrm{I}_{\mathrm{A}}\right)$ was isolated by using voltage protocols, taking advantage of the distinct voltage-dependent inactivation of the underlying potassium channels [22]. First, total voltage-activated potassium current was measured in cells held at $-80 \mathrm{mV}$, in which a $1 \mathrm{~s}$ conditioning pulse to $-100 \mathrm{mV}$ was delivered prior to $250 \mathrm{~ms}$ step depolarizations, ranging from -20 to $+20 \mathrm{mV}$ in $10 \mathrm{mV}$ increments. Then, a depolarizing $1 \mathrm{~s}$ conditioning pulse to $-20 \mathrm{mV}$ was applied, sufficient to inactivate $I_{A}$, such that the outward current evoked by subsequent step depolarizations was mostly comprised of a delayed rectifying potassium current. $\mathrm{I}_{\mathrm{A}}$ was finally revealed by subtracting the delayed rectifying current from total current. Peak amplitude of $\mathrm{I}_{\mathrm{A}}$ was used to determine percent block by IQM-PC332. $\mathrm{I}_{\mathrm{A}}$ inactivation was fitted to a biexponential process with an equation of the form $y=y_{0}+A_{f} \exp -\left(x-x_{0}\right) / \tau_{f}+A_{s} \exp -\left(x-x_{0}\right) / \tau_{s}$, where $\tau_{f}$ and $\tau_{s}$ represent the fast and slow time constants, respectively, and $A_{f}$ and $A_{s}$ represent the amplitudes of the corresponding kinetic components. 
Current trace analysis, curve fitting, and data presentation were performed with Igor Pro 5.0 (Wavemetrics Inc.), Fitmaster (HEKA Electronic, Lambrecht, Germany) and GraphPad Prism 8 (GraphPad Software, La Jolla, CA, USA).

\subsection{Statistics}

Data are given as the mean \pm standard error of the mean (SEM) of the corresponding number of behavioural measurements or cells used. All collected data were first tested for normality as well as for homogeneity of variances. In behavioural experiments, differences between groups were assessed by two-way analysis of variance (ANOVA) for repeated measurements followed by a Bonferroni's test for multiple comparisons. Two-way ANOVA and paired or unpaired Student's $t$-tests were used for data comparisons in electrophysiological experiments. Post hoc tests were run only if $\mathrm{F}$ achieved $p<0.05$, and the threshold for statistical significance was $p<0.05$ throughout. GraphPad Prism 8 (GraphPad Software, La Jolla, CA, USA) was employed for these analyses. Differences with $p<0.05$ were considered significant.

Supplementary Materials: The following supporting information can be downloaded at: https: //www.mdpi.com/article/10.3390/ijms23042142/s1.

Author Contributions: Conceptualization, A.R.A., L.A.O.-O., M.V.B., P.G.S. and M.A.-B.; in vivo experiments, M.V.B., L.A.O.-O., M.A.-B.; in vitro experiments, L.A.O.-O., P.G.S., M.P.P. and M.A.-B.; provide resources, P.C.; formal analysis, A.R.A., L.A.O.-O., M.V.B., P.G.S. and M.A.-B.; visualization, L.A.O.-O., P.G.S., M.V.B. and M.A.-B.; supervision, A.R.A., M.G.-R., J.R.N. and C.V.; writing-original draft preparation, A.R.A.; writing-review and editing, A.R.A., L.A.O.-O., M.V.B., J.R.N., C.V. and M.G.-R. All authors have read and agreed to the published version of the manuscript.

Funding: This research was funded by Universidad Complutense de Madrid grants: PR75/1821593 and FEI20/35 (to A.R.A.), and Ministerio de Ciencia e Innovación, AEI-FEDER, EU grants: SAF2016-75021-R and PID2019-104366RB-C21 (to C.V.), PID2019-109155RB-I00 (to A.R.A.), PID2019104366RB-C22 (to M.G.-R), Instituto de Salud Carlos III CIBERCV program: CB/11/00222 (to C.V.); Consejo Superior de Investigaciones Científicas grants: PIE202180E073 (to M.G.-R.), PIE201820E104 and 2019AEP148 (to C.V.). P.G.S. was funded with a fellowship from the Ministerio de Ciencia e Innovación (FPU17/02731).

Institutional Review Board Statement: The study was conducted according to the guidelines of the Declaration of Helsinki, and approved by the Committee of Animal Experimentation of Universidad Complutense de Madrid and Comunidad de Madrid (PROEX 207.8/21, 29 June 2021).

Informed Consent Statement: Not applicable.

Data Availability Statement: Not applicable.

Acknowledgments: We would like to acknowledge Miguel Ángel Bellón and Mariano Díaz Flores for expert technical assistance.

Conflicts of Interest: The authors declare no conflict of interest.

\section{Abbreviations}

$\begin{array}{ll}\text { BDNF } & \text { Brain derived neurotrophic factor } \\ \mathrm{Ca}_{\mathrm{v}} & \text { Voltage-activated calcium channel/current } \\ \text { CCI } & \text { Chronic constriction injury } \\ \text { DMEM } & \text { Dulbecco's modified Eagle's Medium-low glucose } \\ \text { DREAM } & \text { Downstream regulatory element antagonist modulator } \\ \text { DRG } & \text { Dorsal root ganglia } \\ \text { ED } 50 & \text { Effective dose } 50 \% \\ \text { HVA } & \text { High voltage-activated } \\ \text { IC } 50 & \text { Inhibitory concentration } 50 \% \\ \text { i.p. } & \text { Intraperitoneal } \\ \text { i.pl. } & \text { Intraplantar }\end{array}$




$\begin{array}{ll}\text { IQM-PC332 } & \left(2-[2-(3,4-D i c h l o r o p h e n y l) a c e t y l a m i n o]-4-\left(4^{\prime}-\mathrm{n}-\right.\right. \\ \text { KChIP3 } & \text { Potassium channel interacting protein } 3 \\ \mathrm{~K}_{\mathrm{D}} & \text { Dissociation constant } \\ \mathrm{K}_{\mathrm{v}} & \text { Voltage-activated potassium channel/current } \\ \mathrm{MPE} & \text { Maximum possible effect } \\ \mathrm{Na}_{\mathrm{v}} & \text { Voltage-activated sodium channel/current } \\ \mathrm{PWT} & \text { Paw withdrawal threshold } \\ \mathrm{TRPV} 1 & \text { Transient receptor potential vanilloid-1 } \\ \mathrm{V}_{\mathrm{h}} & \text { Holding voltage } \\ \mathrm{V}_{\mathrm{comm}} & \text { Voltage command } \\ \mathrm{V}_{\mathrm{r}} & \text { Resting membrane potential }\end{array}$

\section{References}

1. Di Stefano, G.; Di Lionardo, A.; Di Pietro, G.; Cruccu, G.; Truini, A. Pharmacotherapeutic Options for Managing Neuropathic Pain: A Systematic Review and Meta-Analysis. Pain Res. Manag. 2021, 2021, 6656863. [CrossRef]

2. St John Smith, E. Advances in Understanding Nociception and Neuropathic Pain. J. Neurol. 2018, 265, 231-238. [CrossRef] [PubMed]

3. Waxman, S.G.; Zamponi, G.W. Regulating Excitability of Peripheral Afferents: Emerging Ion Channel Targets. Nat. Neurosci. 2014, 17, 153-163. [CrossRef]

4. Burgoyne, R.D.; Haynes, L.P. Understanding the Physiological Roles of the Neuronal Calcium Sensor Proteins. Mol. Brain 2012, 5, 2. [CrossRef] [PubMed]

5. Buxbaum, J.D.; Choi, E.K.; Luo, Y.; Lilliehook, C.; Crowley, A.C.; Merriam, D.E.; Wasco, W. Calsenilin: A Calcium-Binding Protein That Interacts with the Presenilins and Regulates the Levels of a Presenilin Fragment. Nat. Med. 1998, 4, 1177-1181. [CrossRef] [PubMed]

6. Carrión, A.M.; Link, W.A.; Ledo, F.; Mellström, B.; Naranjo, J.R. DREAM Is a Ca2+-Regulated Transcriptional Repressor. Nature 1999, 398, 80-84. [CrossRef]

7. An, W.F.; Bowlby, M.R.; Betty, M.; Cao, J.; Ling, H.P.; Mendoza, G.; Hinson, J.W.; Mattsson, K.I.; Strassle, B.W.; Trimmer, J.S.; et al. Modulation of A-Type Potassium Channels by a Family of Calcium Sensors. Nature 2000, 403, 553-556. [CrossRef]

8. Mellstrom, B.; Torres, B.; Link, W.A.; Naranjo, J.R. The BDNF Gene: Exemplifying Complexity in Ca2+ -Dependent Gene Expression. Crit. Rev. Neurobiol. 2004, 16, 43-49. [CrossRef]

9. Rivera-Arconada, I.; Benedet, T.; Roza, C.; Torres, B.; Barrio, J.; Krzyzanowska, A.; Avendaño, C.; Mellström, B.; Lopez-Garcia, J.A.; Naranjo, J.R. DREAM Regulates BDNF-De.ependent Spinal Sensitization. Mol. Pain 2010, 6, 95. [CrossRef]

10. Cheng, H.Y.; Pitcher, G.M.; Laviolette, S.R.; Whishaw, I.Q.; Tong, K.I.; Kockeritz, L.K.; Wada, T.; Joza, N.A.; Crackower, M.; Goncalves, J.; et al. DREAM Is a Critical Transcriptional Repressor for Pain Modulation. Cell 2002, 108, 31-43. [CrossRef]

11. Benedet, T.; Gonzalez, P.; Oliveros, J.C.; Dopazo, J.M.; Ghimire, K.; Palczewska, M.; Mellstrom, B.; Naranjo, J.R. Transcriptional Repressor DREAM Regulates Trigeminal Noxious Perception. J. Neurochem. 2017, 141, 544-552. [CrossRef] [PubMed]

12. Savignac, M.; Pintado, B.; Gutierrez-Adan, A.; Palczewska, M.; Mellström, B.; Naranjo, J.R. Transcriptional Repressor DREAM Regulates T-Lymphocyte Proliferation and Cytokine Gene Expression. EMBO J. 2005, 24, 3555-3564. [CrossRef] [PubMed]

13. Zhang, Y.; Su, P.; Liang, P.; Liu, T.; Liu, X.; Liu, X.Y.; Zhang, B.; Han, T.; Zhu, Y.B.; Yin, D.M.; et al. The DREAM Protein Negatively Regulates the NMDA Receptor through Interaction with the NR1 Subunit. J. Neurosci. 2010, 30, 7575-7586. [CrossRef] [PubMed]

14. Tian, N.X.; Xu, Y.; Yang, J.Y.; Li, L.; Sun, X.H.; Wang, Y.; Zhang, Y. KChIP3 N-Terminal 31-50 Fragment Mediates Its Association with TRPV1 and Alleviates Inflammatory Hyperalgesia in Rats. J. Neurosci. 2018, 38, 1756-1773. [CrossRef]

15. Jerng, H.H.; Pfaffinger, P.J.; Covarrubias, M. Molecular Physiology and Modulation of Somatodendritic A-Type Potassium Channels. Mol. Cell Neurosci. 2004, 27, 343-369. [CrossRef] [PubMed]

16. Anderson, D.; Mehaffey, W.H.; Iftinca, M.; Rehak, R.; Engbers, J.D.; Hameed, S.; Zamponi, G.W.; Turner, R.W. Regulation of Neuronal Activity by Cav3-Kv4 Channel Signaling Complexes. Nat. Neurosci. 2010, 13, 333-337. [CrossRef]

17. Thomsen, M.B.; Wang, C.; Ozgen, N.; Wang, H.G.; Rosen, M.R.; Pitt, G.S. Accessory Subunit KChIP2 Modulates the Cardiac L-Type Calcium Current. Circ. Res. 2009, 104, 1382-1389. [CrossRef]

18. Matsuyoshi, H.; Takimoto, K.; Yunoki, T.; Erickson, V.L.; Tyagi, P.; Hirao, Y.; Wanaka, A.; Yoshimura, N. Distinct Cellular Distributions of Kv4 Pore-Forming and Auxiliary Subunits in Rat Dorsal Root Ganglion Neurons. Life Sci. 2012, 91, $258-263$. [CrossRef]

19. Cheng, C.F.; Wang, W.C.; Huang, C.Y.; Du, P.H.; Yang, J.H.; Tsaur, M.L. Coexpression of Auxiliary Subunits KChIP and DPPL in Potassium Channel Kv4-Positive Nociceptors and Pain-Modulating Spinal Interneurons. J. Comp. Neurol. 2016, 524, 846-873. [CrossRef]

20. Lopez-Hurtado, A.; Peraza, D.A.; Cercos, P.; Lagartera, L.; Gonzalez, P.; Dopazo, X.M.; Herranz, R.; Gonzalez, T.; Martin-Martinez, M.; Mellström, B.; et al. Targeting the Neuronal Calcium Sensor DREAM with Small-Molecules for Huntington's Disease Treatment. Sci. Rep. 2019, 9, 7260. [CrossRef] 
21. Cercós, P.; Peraza, D.A.; Benito-Bueno, A.; Socuéllamos, P.G.; Aziz-Nignan, A.; Arrechaga-Estévez, D.; Beato, E.; Peña-Acevedo, E.; Albert, A.; González-Vera, J.A.; et al. Pharmacological Approaches for the Modulation of the Potassium Channel KV4.x and KChIPs. Int. J. Mol. Sci. 2021, 22, 1419. [CrossRef] [PubMed]

22. Phuket, T.R.; Covarrubias, M. Kv4 Channels Underlie the Subthreshold-Operating A-Type K+-Current in Nociceptive Dorsal Root Ganglion Neurons. Front. Mol. Neurosci. 2009, 2, 3. [CrossRef] [PubMed]

23. Tsantoulas, C.; McMahon, S.B. Opening Paths to Novel Analgesics: The Role of Potassium Channels in Chronic Pain. Trends Neurosci. 2014, 37, 146-158. [CrossRef]

24. Kim, D.S.; Choi, J.O.; Rim, H.D.; Cho, H.J. Downregulation of Voltage-Gated Potassium Channel Alpha Gene Expression in Dorsal Root Ganglia Following Chronic Constriction Injury of the Rat Sciatic Nerve. Brain Res. Mol. Brain Res. 2002, 105, 146-152. [CrossRef]

25. Xiao, Y.; Wu, Y.; Zhao, B.; Xia, Z. Decreased Voltage-Gated Potassium Currents in Rat Dorsal Root Ganglion Neurons after Chronic Constriction Injury. Neuroreport 2016, 27, 104-109. [CrossRef] [PubMed]

26. White, G.; Lovinger, D.M.; Weight, F.F. Transient Low-Threshold Ca2+ Current Triggers Burst Firing through an Afterdepolarizing Potential in an Adult Mammalian Neuron. Proc. Natl. Acad. Sci. USA 1989, 86, 6802-6806. [CrossRef] [PubMed]

27. Bourinet, E.; Alloui, A.; Monteil, A.; Barrère, C.; Couette, B.; Poirot, O.; Pages, A.; McRory, J.; Snutch, T.P.; Eschalier, A.; et al Silencing of the Cav3.2 T-Type Calcium Channel Gene in Sensory Neurons Demonstrates Its Major Role in Nociception. EMBO J. 2005, 24, 315-324. [CrossRef]

28. Chi, X.X.; Schmutzler, B.S.; Brittain, J.M.; Wang, Y.; Hingtgen, C.M.; Nicol, G.D.; Khanna, R. Regulation of N-Type Voltage-Gated Calcium Channels (Cav2.2) and Transmitter Release by Collapsin Response Mediator Protein-2 (CRMP-2) in Sensory Neurons J. Cell Sci. 2009, 122, 4351-4362. [CrossRef]

29. Chaplan, S.R.; Pogrel, J.W.; Yaksh, T.L. Role of Voltage-Dependent Calcium Channel Subtypes in Experimental Tactile Allodynia. J. Pharmacol. Exp. Ther. 1994, 269, 1117-1123.

30. Hatakeyama, S.; Wakamori, M.; Ino, M.; Miyamoto, N.; Takahashi, E.; Yoshinaga, T.; Sawada, K.; Imoto, K.; Tanaka, I.; Yoshizawa, T.; et al. Differential Nociceptive Responses in Mice Lacking the Alpha(1B) Subunit of N-Type Ca(2+) Channels. Neuroreport 2001, 12, 2423-2427. [CrossRef]

31. François, A.; Laffray, S.; Pizzoccaro, A.; Eschalier, A.; Bourinet, E. T-Type Calcium Channels in Chronic Pain: Mouse Models and Specific Blockers. Pflugers Arch. 2014, 466, 707-717. [CrossRef] [PubMed]

32. Patel, R.; Montagut-Bordas, C.; Dickenson, A.H. Calcium Channel Modulation as a Target in Chronic Pain Control. Br. J. Pharmacol. 2018, 175, 2173-2184. [CrossRef] [PubMed]

33. Carbone, E.; Lux, H.D. Kinetics and Selectivity of a Low-Voltage-Activated Calcium Current in Chick and Rat Sensory Neurones. J. Physiol. 1987, 386, 547-570. [CrossRef] [PubMed]

34. Jagodic, M.M.; Pathirathna, S.; Joksovic, P.M.; Lee, W.; Nelson, M.T.; Naik, A.K.; Su, P.; Jevtovic-Todorovic, V.; Todorovic, S.M. Upregulation of the T-Type Calcium Current in Small Rat Sensory Neurons after Chronic Constrictive Injury of the Sciatic Nerve. J. Neurophysiol. 2008, 99, 3151-3156. [CrossRef] [PubMed]

35. Caterina, M.J.; Schumacher, M.A.; Tominaga, M.; Rosen, T.A.; Levine, J.D.; Julius, D. The Capsaicin Receptor: A Heat-Activated Ion Channel in the Pain Pathway. Nature 1997, 389, 816-824. [CrossRef] [PubMed]

36. Arribas-Blázquez, M.; Olivos-Oré, L.A.; Barahona, M.V.; Sánchez de la Muela, M.; Solar, V.; Jiménez, E.; Gualix, J.; McIntosh, J.M.; Ferrer-Montiel, A.; Miras-Portugal, M.T.; et al. Overexpression of P2X3 and P2X7 Receptors and TRPV1 Channels in Adrenomedullary Chromaffin Cells in a Rat Model of Neuropathic Pain. Int. J. Mol. Sci. 2019, 20, 155. [CrossRef]

37. Cobianchi, S.; de Cruz, J.; Navarro, X. Assessment of Sensory Thresholds and Nociceptive Fiber Growth after Sciatic Nerve Injury Reveals the Differential Contribution of Collateral Reinnervation and Nerve Regeneration to Neuropathic Pain. Exp. Neurol. 2014, 255, 1-11. [CrossRef]

38. Kambiz, S.; Baas, M.; Duraku, L.S.; Kerver, A.L.; Koning, A.H.J.; Walbeehm, E.T.; Ruigrok, T.J.H. Innervation Mapping of the Hind Paw of the Rat Using Evans Blue Extravasation, Optical Surface Mapping and CASAM. J. Neurosci. Methods 2014, 229 , 15-27. [CrossRef]

39. Attal, N.; Filliatreau, G.; Perrot, S.; Jazat, F.; Di Giamberardino, L.; Guilbaud, G. Behavioural Pain-Related Disorders and Contribution of the Saphenous Nerve in Crush and Chronic Constriction Injury of the Rat Sciatic Nerve. Pain 1994, 59, 301-312. [CrossRef]

40. Julius, D. TRP Channels and Pain. Annu. Rev. Cell Dev. Biol. 2013, 29, 355-384. [CrossRef]

41. Cardoso, F.C.; Lewis, R.J. Sodium Channels and Pain: From Toxins to Therapies. Br. J. Pharmacol. 2018, 175, 2138-2157. [CrossRef] [PubMed]

42. Scroggs, R.S.; Fox, A.P. Multiple Ca2+ Currents Elicited by Action Potential Waveforms in Acutely Isolated Adult Rat Dorsal Root Ganglion Neurons. J. Neurosci. 1992, 12, 1789-1801. [CrossRef] [PubMed]

43. Westenbroek, R.E.; Hoskins, L.; Catterall, W.A. Localization of Ca2+ Channel Subtypes on Rat Spinal Motor Neurons, Interneurons, and Nerve Terminals. J. Neurosci. 1998, 18, 6319-6330. [CrossRef]

44. Rose, K.E.; Lunardi, N.; Boscolo, A.; Dong, X.; Erisir, A.; Jevtovic-Todorovic, V.; Todorovic, S.M. Immunohistological Demonstration of CaV3.2 T-Type Voltage-Gated Calcium Channel Expression in Soma of Dorsal Root Ganglion Neurons and Peripheral Axons of Rat and Mouse. Neuroscience 2013, 250, 263-274. [CrossRef] [PubMed] 
45. Peraza, D.M. Efectos Electrofisiológicos de PC332 Y PC342 Sobre Los Canales Kv4.3 y Kv4.3+KChIP3. Master's Thesis, Universidad Autónoma de Madrid, Madrid, Spain, 2015.

46. Santicioli, P.; Del Bianco, E.; Tramontana, M.; Geppetti, P.; Maggi, C.A. Release of Calcitonin Gene-Related Peptide likeImmunoreactivity Induced by Electrical Field Stimulation from Rat Spinal Afferents Is Mediated by Conotoxin-Sensitive Calcium Channels. Neurosci. Lett. 1992, 136, 161-164. [CrossRef]

47. Terashima, T.; Xu, Q.; Yamaguchi, S.; Yaksh, T.L. Intrathecal P/Q- and R-Type Calcium Channel Blockade of Spinal Substance P Release and c-Fos Expression. Neuropharmacology 2013, 75, 1-8. [CrossRef]

48. Jacus, M.O.; Uebele, V.N.; Renger, J.J.; Todorovic, S.M. Presynaptic Cav3.2 Channels Regulate Excitatory Neurotransmission in Nociceptive Dorsal Horn Neurons. J. Neurosci. 2012, 32, 9374-9382. [CrossRef] [PubMed]

49. Hogan, Q.H. Role of Decreased Sensory Neuron Membrane Calcium Currents in the Genesis of Neuropathic Pain. Croat. Med. J. 2007, 48, 9-21.

50. Vydyanathan, A.; Wu, Z.Z.; Chen, S.R.; Pan, H.L. A-Type Voltage-Gated K+ Currents Influence Firing Properties of Isolectin B4-Positive but Not Isolectin B4-Negative Primary Sensory Neurons. J. Neurophysiol. 2005, 93, 3401-3409. [CrossRef]

51. Wang, Z.; Ling, D.; Wu, C.; Han, J.; Zhao, Y. Baicalin Prevents the Up-Regulation of TRPV1 in Dorsal Root Ganglion and Attenuates Chronic Neuropathic Pain. Vet. Med. Sci. 2020, 6, 1034-1040. [CrossRef]

52. Jerng, H.H.; Pfaffinger, P.J. Modulatory Mechanisms and Multiple Functions of Somatodendritic A-Type K (+) Channel Auxiliary Subunits. Front. Cell Neurosci. 2014, 8, 82. [CrossRef] [PubMed]

53. Guo, Y.P.; Zhi, Y.R.; Liu, T.T.; Wang, Y.; Zhang, Y. Global Gene Knockout of Kcnip3 Enhances Pain Sensitivity and Exacerbates Negative Emotions in Rats. Front. Mol. Neurosci. 2019, 12, 5. [CrossRef] [PubMed]

54. Bennett, G.J.; Xie, Y.K. A Peripheral Mononeuropathy in Rat That Produces Disorders of Pain Sensation like Those Seen in Man. Pain 1988, 33, 87-107. [CrossRef]

55. Arribas-Blázquez, M.; Olivos-Oré, L.A.; Barahona, M.V.; Wojnicz, A.; De Pascual, R.; Sánchez de la Muela, M.; García, A.G.; Artalejo, A.R. The Adrenal Medulla Modulates Mechanical Allodynia in a Rat Model of Neuropathic Pain. Int. J. Mol. Sci. 2020, 21, 8325. [CrossRef]

56. Carabelli, V.; Giancippoli, A.; Baldelli, P.; Carbone, E.; Artalejo, A.R. Distinct Potentiation of L-Type Currents and Secretion by CAMP in Rat Chromaffin Cells. Biophys. J. 2003, 85, 1326-1337. [CrossRef] 